\title{
Efficacy of Clonostachys rosea, as a promising entomopathogenic fungus, against coleopteran stored product insect pests under laboratory conditions
}

\author{
Akram A. Mohammed ${ }^{1 *}$ D, Amal S. Younus ${ }^{1,2}$ and Abdulla N. Ali
}

\begin{abstract}
Background: Efficacy of new isolates of the entomopathogenic fungus (EPF), Clonostachys rosea, against adult stage of the most serious coleopteran stored product insect pests in Iraq, Trogoderma granarium Everts (Coleoptera: Dermestidae), Tribolium castaneum Herbst (Coleoptera: Tenebrionidae) and Callosobruchus maculatus Fabricius (Coleoptera: Chrysomelidae), was evaluated under laboratory conditions. Two isolates of C. rosea, associated with the green peach aphid (Myzus persicae Sulz.), were isolated and investigated. Efficacy of $C$. rosea isolates was

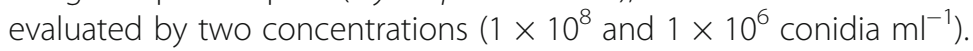

Results: Corrected mortality rates caused by both $C$. rosea isolates, 6 days post-treatment, with $1 \times 10^{8}$ conidia $\mathrm{ml}^{-1}$, ranged from 70.7 to $75.7 \%$. Fungal infection caused $37-53 \%$ reduction in total fecundity of the adult females of the three tested insect species, 6 days post-treatment.

Conclusion: Obtained results demonstrated that C. rosea isolates had potentials as a biological control agent against coleopteran stored product insect pests. However, further studies under commercial storage conditions are required.
\end{abstract}

Keywords: Entomopathogenic fungus, Clonostachys rosea, Stored product insect pests, Trogoderma granarium, Tribolium castaneum, Callosobruchus maculatus, Potential, Iraq

\section{Background}

The khapra beetle Trogoderma granarium Everts (Coleoptera: Dermestidae), the red flour beetle Tribolium castaneum Herbst (Coleoptera: Tenebrionidae) and the cowpea weevil Callosobruchus maculatus Fabricius (Coleoptera: Chrysomelidae) are among the most important and widespread insect pests of stored grains and products worldwide (Lal et al. 2017). These stored insect pests cause economic damages including seed weight loss, decrease of market value, decrease in germination viability of seeds and decrease in nutritional value, particularly proteins (García-Lara and Saldivar 2016).

\footnotetext{
* Correspondence: akrama.abodarb@uokufa.edu.iq

${ }^{1}$ Plant Protection Department, University of Kufa, Najaf, Iraq

Full list of author information is available at the end of the article
}

Chemical insecticides such as cypermethrin, deltamethrin and pirimiphos-methyl are still the main control method to manage these stored insect pests. However, extensive use of such chemical insecticides has been associated with many problems (Kavallieratos et al. 2017) including development of insecticide resistance, negative effects on human and animal health and other nontarget organisms and environmental contamination (Koureas et al. 2012). To reduce the adverse effects of insecticides, scientists are attempting to develop alternative methods for management of these insect pests in storage environments.

Microbial control agents have been widely used as alternatives for controlling stored insect pests (Mohammed et al. 2019). Several entomopathogenic fungi (EPF), 
such as Metarhizium anisopliae Metchnikoff (Hypocreales: Clavicipitaceae), Beauveria bassiana Bals.-Criv. (Hypocreales: Cordycipitaceae), Lecanicillium spp. Gams and Zare (Hypocreales: Cordycipitaceae) and Isaria fumosorosea Wize (Hypocreales: Clavicipitaceae) have been well reported as a promising biocontrol agent of stored insect pests including T. granarium (Mohammed et al. 2019) T. castaneum (Rehman et al. 2020) and $C$. maculatus (Ozdemir et al. 2020).

The entomopathogenic fungus (EPF), Clonostachys rosea Schroers (Hypocreales: Bionectriaceae) (formerly Gliocladium roseum), has a broad-spectrum mycoparasite effect on reducing the growth and associated diseases of several plant-pathogenic fungi, including Alternaria spp. Nees (Pleosporales: Pleosporaceae), Bipolaris sorokiniana Drechsler ex Dastur (Pleosporales: Pleosporaceae), Botrytis cinerea Pers. (Helotiales: Sclerotiniaceae) and Fusarium culmorum Sacc. (Hypocreales: Nectriaceae) (Xue 2003; Jensen et al. 2004; Nobre et al. 2005). Potential effects of $C$. rosea as a microbial control agent for the control of insect species including leafhopper, Sonesimia grossa and Oncometopia tucumana (Hemiptera: Cicadellidae) (Toledo et al. 2006), and sweet potato whitefly, Bemisia tabaci Gennadius (Hemiptera: Aleyrodidae) (Anwar et al. 2018), have been also reported. However, there are no available published articles on the efficacy of $C$. rosea isolates as EPF against stored product insect pests. Thus, such information may help in developing management strategies of utilizing microbial control as part of an integrated pest management strategy against $T$. granarium, $T$. castaneum and C. maculatus.

The objective of this study was to evaluate the biocontrol potential of two $C$. rosea isolates against the most important stored product insect pests (T. granarium, $T$. castaneum and C. maculatus) under laboratory conditions. The effect of fungal infection on the fecundity of the studied insect species was also examined.

\section{Methods}

\section{Insect culture}

Colonies of T. granarium, T. castaneum and C. maculatus were collected initially from the Entomology Laboratory, Faculty of Agriculture, Iraq. Insects of each species (50 male and female pairs) were reared on their main stored product in 300-ml plastic jars, secured with a

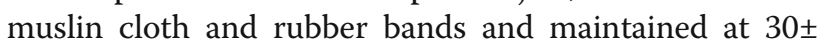
$2^{\circ} \mathrm{C}$ and $65 \pm 3 \% \mathrm{RH}$ at continuous darkness for 2 generations. Grains were sterilized by placing them in a freezer (Samsung Ltd, Thailand) at $-20^{\circ} \mathrm{C}$ for at least 2 days before each experiment. T. granarium was reared on whole sterilized wheat grains, C. maculatus was reared on sterilized cowpeas (Vigna unguiculata L. var. Parastoo) and T. castaneum was reared on sterilized wheat flour.
Adults were removed after 5 days, and wheat grains, cowpea grains and wheat flour with the insect eggs were maintained under the laboratory conditions described above. Same-age cohorts of adult T. granarium, T. castaneum, or C. maculatus were obtained after 40-45 days and used in the treatments.

\section{Source and preparation of $C$. rosea isolates}

Two isolates of C. rosea [AA80 (MT366561) and AA82 (MT366214)] were obtained from dead M. persicae adults, collected from a greenhouse at the Faculty of Agriculture. Isolates were identified as C. rosea, following general and specific identification keys of Schroers et al. (1999). DNA amplification, sequencing and phylogenetic analysis technique were used to confirm morphological identification. Both isolates were cultivated on Sabouraud dextrose peptone yeast extract agar (SDAY) at $25^{\circ} \mathrm{C}$. Aerial conidia were harvested from 14day-old cultures by adding $15 \mathrm{ml}$ of $0.01 \%$ Tween 80 to culture agar Petri dishes and gently scraping the surface of the cultures with a sterile inoculating loop to dislodge the conidia from the surface of the agar plates. The conidial suspension was pipetted from the Petri dish and filtered through 3 layers of cheesecloth. The number of conidia in the suspension was estimated, using a haemocytometer (Neubauer improved, Superior Marienfeld, Germany). The resulted suspension was diluted to the desired concentrations with $0.01 \%$ Tween 80 as required. The viability of the conidia was determined by spraying $\left(0.1 \mathrm{ml}\right.$ of $1 \times 10^{6}$ conidia $\left.\mathrm{ml}^{-1}\right)$ on a sterile Petri dish with $1.5 \%$ SDAY. The dishes were sealed by a parafilm and incubated at $20^{\circ} \mathrm{C}, 90 \pm 2 \% \mathrm{RH}$, and a photoperiod of 16:8 (L:D) h. After $24 \mathrm{~h}$, the number of germinated spores per 100 spores of each Petri dish was assessed under the microscope $(\times 400$ magnification). Germination was considered positive when the length of germ tube was at least half of the spore length. The viability exceeded $96 \%$ for both isolates.

\section{Virulence of $C$. rosea isolates}

Ten Petri dish replicates, each with 5 pairs (male and female adults), were used for each EPF isolate and control $(0.02 \%$ sterile aqueous Tween 80 only) for either $T$. granarium, T. castaneum, or C. maculatus. Whatman No. 1 filter paper was placed in a Petri dish. Afterwards, pairs of each of $T$. granarium, $T$. castaneum, or $C$. maculatus were released into the dishes and sprayed with $2 \mathrm{ml}$ of conidial concentrations of each C. rosea isolate $\left(1 \times 10^{6}\right.$ or $1 \times 10^{8}$ conidia ml $\left.{ }^{-1}\right)$, using 11 handheld sprayer and air-dried for $30 \mathrm{~min}$ at room temperature. Then, $5 \mathrm{~g}$ of sterilized wheat grain, cowpea grain or wheat flour were added to each Petri dish. All Petri dishes were sealed by a parafilm and incubated at $25 \pm 2^{\circ} \mathrm{C}, 70 \pm 2 \% \mathrm{RH}$ and a photoperiod of $12: 12$ (L:D) $\mathrm{h}$. 
Table 1 The corrected mortalities of Callosobruchus maculatus, Trogoderma granarium and Tribolium castaneum adults treated with conidia of two Clonostachys rosea isolates. The conidial concentration of each entomopathogenic fungal isolate used for treatment was $1 \times 10^{8}$ conidia $\mathrm{ml}^{-1}$

\begin{tabular}{|c|c|c|c|c|c|c|c|}
\hline \multirow[t]{2}{*}{ Insect species } & \multirow[t]{2}{*}{ EPF isolate } & \multicolumn{6}{|c|}{ Corrected mortality (\%) } \\
\hline & & 1 day & 2 days & 3 days & 4 days & 5 days & 6 days \\
\hline \multirow[t]{2}{*}{ Callosobruchusmaculatus } & Clonostachys rosea isolate AA80 & $0.0 \mathrm{aA}$ & $3.0 \mathrm{aA}$ & $20.0 \mathrm{aB}$ & $38.2 \mathrm{aC}$ & $57.3 \mathrm{aD}$ & $75.7 \mathrm{aE}$ \\
\hline & Clonostachysrosea isolate AA82 & $0.0 \mathrm{aA}$ & $2.0 \mathrm{aA}$ & $21.4 \mathrm{aB}$ & $39.1 \mathrm{aC}$ & $58.0 \mathrm{aD}$ & $75.1 \mathrm{aE}$ \\
\hline \multirow[t]{2}{*}{ Trogoderma granarium } & Clonostachysrosea isolate AA80 & $0.0 \mathrm{aA}$ & $0.0 \mathrm{aA}$ & $19.0 \mathrm{aB}$ & $37.0 \mathrm{aC}$ & $57.2 \mathrm{aD}$ & $73.5 \mathrm{aE}$ \\
\hline & Clonostachys rosea isolate AA82 & $0.0 \mathrm{aA}$ & $1.0 \mathrm{aA}$ & $20.0 \mathrm{aB}$ & $36.1 \mathrm{abc}$ & $55.0 \mathrm{abD}$ & $71.7 \mathrm{abE}$ \\
\hline \multirow[t]{2}{*}{ Tribolium castaneum } & Clonostachys rosea isolate AA80 & $0.0 \mathrm{aA}$ & $0.0 \mathrm{aA}$ & $17.6 \mathrm{aB}$ & $34.8 \mathrm{bc}$ & $54.9 \mathrm{bD}$ & $70.7 \mathrm{abE}$ \\
\hline & Clonostachys rosea isolate AA82 & $0.0 \mathrm{aA}$ & $0.0 \mathrm{aA}$ & $17.4 \mathrm{aB}$ & $35.3 \mathrm{bc}$ & $53.2 \mathrm{bD}$ & $71.4 \mathrm{bE}$ \\
\hline
\end{tabular}

Values within a column followed by the same lowercase letters indicate no significant differences among insect species of both EPF isolates; values within a row followed by different uppercase letters indicate significant differences among days after treatment within each insect species and EPF isolate combination at $P=0$ .05 using LSD test

Mortality rate was recorded daily for 6 days only, because the number of dead T. granarium and C. maculatus in the control significantly increased after 6 days of treatment, which was likely to influence the death rate of the fungus-treated insects. Dead insects were surface sterilized by rinsing twice with $70 \%$ ethanol for $30 \mathrm{sec}$, then rinsed with sterilized distilled water, before being placed on water agar ( $3 \mathrm{~g}$ of agar/l of water) in $9-\mathrm{cm}$ Petri dishes for 5 days to confirm infection by EPF (Mohammed and Hatcher 2016). Cadavers were regarded as died from infection with these fungi, if conidia were recovered from the cadavers. The median lethal time $\left(\mathrm{LT}_{50}\right)$ values for each fungal isolate were calculated. The entire experiment was repeated twice.

\section{Effect of $C$. rosea treatment on the fecundity of coleopteran stored pests}

The effect of infection with $C$. rosea isolates on the fecundity was determined for $T$. granarium, $T$. castaneum and $C$. maculatus adult females, male-female (1-2 days old) pairs of each insect species (each pair was a replicate). The experiment followed the method described in the 'Virulence of $\mathrm{C}$. rosea isolates' section, where each pair was sprayed by $2 \mathrm{ml}$ of each fungal isolate at a concentration of $1 \times 10^{6}$ conidia $\mathrm{ml}^{-1}$. Insects in the control treatment were treated by $0.02 \%$ sterile aqueous Tween 80 only. Each treatment was replicated 20 times. The number of eggs produced by each female was recorded daily until the female's death using a magnifying lens.

\section{Statistical analysis}

Cumulative mortality was corrected for natural death in the control using Abbott's formula (Abbott 1925). Normal distribution of data was assessed, using the ShapiroWilk test. Corrected mortalities were login transformed when necessary to meet the assumption of normality. Data used to determine the $\mathrm{LT}_{50}$ values of C. rosea isolates were calculated, using the probit analysis method. Two-factor repeated measurement was used to determine the effect of fungal isolate and insect species on the efficacy of $C$. rosea isolates. The effect of fungal infection on the fecundity of either T. granarium, T. castaneum or C. maculatus adult females was analysed separately using one-way repeated measurement ANOVA. Mean comparisons were performed using LSD test at $5 \%$ level of significance $(\mathrm{P}<.05)$.

Table 2 Median lethal time ( $L T_{50}$ ) of two isolates of Clonostachys rosea against adult stage of Callosobruchus maculatus, Trogoderma granarium and Tribolium castaneum. The conidial concentration of each entomopathogenic fungal isolate used for treatment was 1 $\times 10^{8}$ conidia $\mathrm{ml}^{-1}$

\begin{tabular}{|c|c|c|c|c|c|}
\hline Insect species & EPF isolate & Slope \pm SE [log 10 (dose)] & $\mathrm{LT}_{50}$ & $95 \% \mathrm{CL}$ & $x^{2}$ \\
\hline \multirow[t]{2}{*}{ Callosobruchus maculatus } & Clonostachys rosea isolate AA80 & $3.28 \pm 0.69$ & 4.83 & $4.30-5.63$ & 1.54 \\
\hline & Clonostachys rosea isolate AA82 & $3.77 \pm 0.45$ & 4.79 & $4.04-5.80$ & 2.73 \\
\hline \multirow[t]{2}{*}{ Trogoderma granarium } & Clonostachys rosea isolate AA80 & $4.12 \pm 0.82$ & 4.81 & $4.23-6.11$ & 0.96 \\
\hline & Clonostachys rosea isolate AA82 & $2.98 \pm 0.57$ & 4.86 & $4.35-5.95$ & 1.79 \\
\hline \multirow[t]{2}{*}{ Tribolium castaneum } & Clonostachys rosea isolate AA80 & $3.49 \pm 0.72$ & 4.93 & $4.47-6.24$ & 2.48 \\
\hline & Clonostachys rosea isolate AA82 & $4.32 \pm 0.84$ & 4.95 & $4.15-6.33$ & 1.24 \\
\hline
\end{tabular}


Table 3 The corrected mortalities of Callosobruchus maculatus, Trogoderma granarium and Tribolium castaneum adults treated with conidia of two Clonostachys rosea isolates. The conidial concentration of each entomopathogenic fungal isolate used for treatment was $1 \times 10^{6}$ conidia $\mathrm{ml}^{-1}$

\begin{tabular}{llllllll}
\hline Insect species & EPF isolate & \multicolumn{2}{l}{ Corrected } & & \\
\cline { 3 - 7 } & & $\mathbf{1}$ day & $\mathbf{2}$ days & $\mathbf{3}$ days & $\mathbf{4}$ days & $\mathbf{5}$ days & $\mathbf{6}$ days \\
\hline Callosobruchus maculatus & Clonostachys rosea isolate AA80 & $0.0 \mathrm{aA}$ & $2.0 \mathrm{aA}$ & $9.0 \mathrm{aB}$ & $27.2 \mathrm{aC}$ & $41.3 \mathrm{aD}$ & $50.7 \mathrm{aE}$ \\
& Clonostachys rosea isolate AA82 & $0.0 \mathrm{aA}$ & $0.0 \mathrm{aA}$ & $9.4 \mathrm{aB}$ & $26.1 \mathrm{aC}$ & $41.0 \mathrm{aD}$ & $50.1 \mathrm{aE}$ \\
\multirow{2}{*}{ Trogoderma granarium } & Clonostachys rosea isolate AA80 & $0.0 \mathrm{aA}$ & $0.0 \mathrm{aA}$ & $8.3 \mathrm{aB}$ & $24.7 \mathrm{aC}$ & $38.2 \mathrm{aD}$ & $50.5 \mathrm{aE}$ \\
& Clonostachys rosea isolate AA82 & $0.0 \mathrm{aA}$ & $1.0 \mathrm{aA}$ & $8.6 \mathrm{aB}$ & $25.6 \mathrm{aC}$ & $39.0 \mathrm{aD}$ & $49.7 \mathrm{aE}$ \\
Tribolium castaneum & Clonostachys rosea isolate AA80 & $0.0 \mathrm{aA}$ & $0.0 \mathrm{aA}$ & $7.6 \mathrm{aB}$ & $24.8 \mathrm{aC}$ & $38.9 \mathrm{aD}$ & $47.7 \mathrm{aE}$ \\
& Clonostachys rosea isolate AA82 & $0.0 \mathrm{aA}$ & $0.0 \mathrm{aA}$ & $8.4 \mathrm{aB}$ & $25.3 \mathrm{aC}$ & $39.2 \mathrm{aD}$ & $48.4 \mathrm{aE}$ \\
\hline
\end{tabular}

Values within a column followed by the same lowercase letters indicate no significant differences among insect species of both EPF isolates; values within a row followed by different uppercase letters indicate significant differences among days after treatment within each insect species and EPF isolate combination at $P=0$ .05 using LSD test

\section{Results}

Virulence of $C$. rosea isolates

The pathogenicity of two isolates of $C$. rosea [AA80 (MT366561) and AA82 (MT366214)] was investigated against adults of $T$. granarium, $T$. castaneum and $C$. maculatus, using 2 conidial concentrations $\left(1 \times 10^{8}\right.$ and $1 \times 10^{6}$ conidia $\mathrm{ml}^{-1}$ ). The results showed that conidial concentration of both $C$. rosea isolates significantly affected the corrected mortality of all the 3 tested species of insect adults after 6 days of application $\left(F_{(1,719)}=\right.$ 176.92; $P<0.001)$. The effect of time after fungal application on the rate of corrected mortality was also significant $\left(F_{(5,719)}=265.45 ; P<0.001\right)$, but there were non-significant differences between both fungal isolates $\left(F_{(1,719)}=0.26 ; P=0.61\right)$ and insect species $\left(F_{(2,719)}=\right.$ $1.27 ; P=0.17)$. Corrected mortality of the 3 tested species of insect adults treated with the conidial concentration of $1 \times 10^{8}$ conidia $\mathrm{ml}^{-1}$ began 3 days post incubation, had a high percent mortality for both $C$. rosea isolates after 6 days and ranged between 70.7 and $75.7 \%$ (Table 1). Both C. rosea isolates showed the $\mathrm{LT}_{50}$ values ranged from 4.79 to 4.95 days (Table 2). Corrected mortality of T. granarium, T. castaneum and C. maculatus adults treated with either $C$. rosea isolate AA80 or $C$. rosea isolate AA82 at a conidial concentration of $1 \times 10^{6}$ conidia $\mathrm{ml}^{-1}$ after 6 days ranged from 47.7 to $50.7 \%$ (Table 3). Mortality in control treatments ranged between 8 and $10 \%$.

\section{Effect of C. rosea treatment on the fecundity of coleopteran stored pests}

The fecundity of adult females of each of the 3 species tested, T. granarium, T. castaneum and C. maculatus, was affected by the treatment with $C$. rosea isolates $(T$. granarium: $F_{(2,44)}=199.51 ; P<0.001 ; T$. castaneum: $F$ ${ }_{(2,44)}=173.22 ; P<0.001 ; C$. maculatus: $F_{(2,44)}=$ $122.31 ; P<0.001)$. The average number of eggs produced per $T$. granarium adult female in the control was $144.7 \pm 8.6$ eggs, which was higher than those exposed to both $C$. rosea isolates: AA80 (80.6 \pm 6.5 eggs) and isolate AA82 (88.9 \pm 9.1 eggs). The average number of eggs produced per $T$. castaneum adult female was $44.6 \pm 4.5$ eggs in control, which was higher than those exposed to both $C$. rosea isolates (Table 4). The average number of

Table 4 Effect of fungal infection on the mean numbers of eggs produced per adult female of either Callosobruchus maculatus, Trogoderma granarium or Tribolium castaneum compared to the control

\begin{tabular}{lll}
\hline Insect species & Treatment & Total fecundity mean No. of eggs per female $( \pm$ SE) \\
\hline Callosobruchus maculatus & Clonostachys rosea isolate AA80 & $60.8 \pm 5.2 \mathrm{~b}$ \\
& Clonostachys rosea isolate AA82 & $58.2 \pm 4.4 \mathrm{~b}$ \\
Trogoderma granarium & Control & $92.3 \pm 7.6 \mathrm{a}$ \\
& Clonostachys rosea isolate AA80 & $80.6 \pm 6.5 \mathrm{~b}$ \\
Tribolium castaneum & Clonostachys rosea isolate AA82 & $88.9 \pm 9.1 \mathrm{~b}$ \\
& Control & $144.7 \pm 8.6 \mathrm{a}$ \\
& Clonostachys rosea isolate AA80 & $24.8 \pm 2.9 \mathrm{~b}$ \\
& Clonostachys rosea isolate AA82 & $21.6 \pm 3.1 \mathrm{~b}$ \\
& Control & $44.6 \pm 4.5 \mathrm{a}$
\end{tabular}


eggs produced per C. maculatus adult female in control was $92.30 \pm 7.6$ eggs, which was higher than those exposed to both C. rosea isolates (Table 4).

\section{Discussion}

Several studies have investigated the efficacy of different EPF isolates against stored grain pests (Khashaveh et al. 2011; Mohammed et al. 2019). The present study evaluated the efficacy of 2 different isolates of $C$. rosea against adult stages of $T$. granarium, $T$. castaneum and $C$. maculatus. The results showed that high concentration of both EPF isolates against all the 3 in the laboratory resulted in high levels of mortality, 6 days post the treatment. In addition, results reported that both $C$. rosea isolates had the $\mathrm{LT}_{50}$ values ranged from 4.79 to 4.95 days. The results concluded that $C$. rosea isolates displayed a potential as an important biological control of stored grain pests.

It is important for EPF to determine the optimal conidial concentration and lethal time to kill $50 \%\left(\mathrm{LT}_{50}\right)$ of treated insect hosts also, to reduce the overall cost of insect pest control and achieving a high level of control. The results of the present study suggested $\left(1 \times 10^{8}\right.$ conidia $\mathrm{ml}^{-1}$ ) for both $C$. rosea isolates as the recommended concentration to control the coleopteran stored product insect pests under laboratory conditions. However, more experiments are needed to evaluate this application in commercial storage conditions. The results obtained are consistent with those of Toledo et al. (2006) who recorded (82.5\%) mortality rate of O. tucumana after 2 weeks of inoculation with $C$. rosea at a conidial concentration $\left(1 \times 10^{8}\right.$ conidia $\left.\mathrm{ml}^{-1}\right)$. Uses of different insect hosts, environmental conditions and/or application methods have showed different results.

The results obtained in the present study led to accept the hypotheses that individuals of insects treated with EPE produce eggs at a different rate compared to untreated insects. The reduction in total fertility in infected insects is consistent with the results obtained by Mohammed et al. (2019) with other EPFs, who found that infection with $B$. bassiana isolate $\mathrm{Bb} 25$ and $M$. anisopliae isolate Ma42 showed (50\%) reduction in total fertility of T. granarium females, than in the untreated ones. In addition, Fargues et al. (1991) reported that infection with $B$. bassiana reduced the total fecundity of Colorado potato beetle, Leptinotarsa decemlineata Say (Coleoptera: Chrysomelidae), about 56\% than in the untreated females. The indirect effect of EPF infection on the daily and total fecundity of stored product insect pests may be related to histological and cytological damage of the ovaries of treated T. granarium, T. castaneum and C. maculatus (Mohammed et al. 2019). Second, EPF can produce secondary metabolites, which may interfere egg production (Furlong et al. 1997). The decrease in total fecundity of infected coleopteran stored product pests of the present study could result from killing of adult females so that the duration of their reproductive period is effectively shortened. Furthermore, infection with certain EPF can cause muscle paralysis (tetany), followed by muscle weakness in infected insect hosts before death, which may reduce the number of eggs produced by infected females (Samuels et al. 1988).

\section{Conclusions}

The entomopathogenic fungus, $C$. rosea isolates, showed potential against the 3 stored product insect pests: $T$. granarium, T. castaneum and C. maculatus under laboratory conditions. As well, reductions in total fertility of the infected target insect pests were also recorded. However, further studies are required to confirm the efficacy of $C$. rosea isolates under commercial storage conditions. In addition, the potential effects of $C$. rosea in combination with some other control methods are also required to be evaluated.

\section{Abbreviations \\ EPF: Entomopathogenic fungi; RH: Relative humidity; SDA: Sabouraud dextrose agar}

\section{Acknowledgements}

The authors wish to thank the Laboratory of Fungi, Plant Protection Department, Faculty of Agriculture, University of Kufa, for providing us with the entomopathogenic fungi used in this study.

\section{Authors' contributions}

AAM, ASA and ANA designed and carried out all experiments, recorded the data and interpreted the results. AAM analysed the data and wrote the first draft of the manuscript. All authors read and approved the final manuscript.

\section{Funding}

Not applicable.

Availability of data and materials

All data and materials are available.

\section{Declarations}

Ethics approval and consent to participate Not applicable.

Consent for publication

Not applicable.

\section{Competing interests}

The authors declare no competing interests.

\section{Author details}

${ }^{1}$ Plant Protection Department, University of Kufa, Najaf, Iraq. ${ }^{2}$ Al-najaf Directorate of Agriculture, Ministry of Agriculture, Najaf, Iraq.

Received: 21 January 2021 Accepted: 15 March 2021

Published online: 20 March 2021

\section{References \\ Abbott WS (1925) A method of computing the effectiveness of an insecticide. J Econ Entomol 18(2):265-267. https://doi.org/10.1093/jee/18.2.265a Anwar W, Ali S, Nawaz K, Iftikhar S, Javed MA, Hashem A, Alqarawi AA, Abd Allah EF, Akhter A (2018) Entomopathogenic fungus Clonostachys rosea as a}


biocontrol agent against whitefly (Bemisia tabaci). Biocontrol Sci Tech 28(8): 750-760. https://doi.org/10.1080/09583157.2018.1487030

Fargues J, Delmas JC, Auge J, Lebrun RA (1991) Fecundity and egg fertility in the adult Colorado beetle (Leptinotarsa decemlineata) surviving larval infection by the fungus Beauveria bassiana. Entomol Exp Appl 61 (1):45-51. https://doi. org/10.1111/j.1570-7458.1991.tb02394.x

Furlong MJ, Reddy GVP, Pell JK, Poppy GM (1997) Pre-mortality effects of Zoophthora radicans infection in the diamondback moth. In: Proceedings: the management of diamondback moth and other crucifer pests, pp 116-122

García-Lara S, Saldivar SS (2016) Insect pests. In: Encyclopedia of food and health. Waltham: Elsevier; pp 432-436

Jensen B, Knudsen IMB, Madsen M, Jensen DF (2004) Biopriming of infected carrot seed with an antagonist, Clonostachys rosea, selected for control of seedborne Alternaria spp. Phytopathology 94(6):551-560. https://doi.org/10.1 094/PHYTO.2004.94.6.551

Kavallieratos N, Athanassiou C, Boukouvala G, Diamantis C, Boukouvala N (2017) Evaluation of six insecticides against adults and larvae of Trogoderma granarium Everts (Coleoptera: Dermestidae) on wheat, barley, maize and rough rice. J Stored Prod Res 71:81-92. https:/doi.org/10.1016/j.jppr.2016.12.003

Khashaveh A, Safaralizadeh MH, Ghosta Y (2011) Pathogenicity of Iranian isolates of Metarhizium anisopliae (Metschinkoff) (Ascomycota: Hypocreales) against Trogoderma granarium Everts (Coleoptera: Dermestidae). Biharean Biol 5:5155

Koureas M, Tsakalof A, Tsatsakis A, Hadjichristodoulou C (2012) Systematic review of biomonitoring studies to determine the association between exposure to organophosphorus and pyrethroid insecticides and human health outcomes. Toxicol Lett 210(2):155-168. https://doi.org/10.1016/j.toxlet.2011.10.007

Lal M, Ram B, Tiwari P (2017) Botanicals to cope stored grain insect pests: a review. Int J Curr Microbiol Appl Sci 6(6):1583-1594. https://doi.org/10.20546/ ijcmas.2017.606.186

Mohammed AA, Hatcher PE (2016) Effect of temperature, relative humidity and aphid developmental stage on the efficacy of the mycoinsecticide Mycotal ${ }^{\circ}$ against Myzus persicae. Biocontrol Sci Tech 26(10):1379-1400. https://doi. org/10.1080/09583157.2016.1207219

Mohammed AA, Kadhim JH, Hasan AMH (2019) Laboratory evaluation of entomopathogenic fungi for the control of khapra beetle (Coleoptera: Dermestidae) and their effects on the beetles' fecundity and longevity. J Agr Urban Entomol 35(1):1-11. https://doi.org/10.3954/1523-5475-35.1.1

Nobre SAM, Maffia LA, Mizubuti ESG, Cota LV, Dias APS (2005) Selection of Clonostachys rosea isolates from Brazilian ecosystems effective in controlling Botrytis cinerea. Biol Control 34(2):132-143. https://doi.org/10.1016/j. biocontrol.2005.04.011

Ozdemir IO, Tuncer C, Erper I, Kushiyev R (2020) Efficacy of the entomopathogenic fungi; Beauveria bassiana and Metarhizium anisopliae against the cowpea weevil, Callosobruchus maculatus F. (Coleoptera: Chrysomelidae: Bruchinae). Egypt J Biol Pest Control 30(1):20-24

Rehman H, Rasul A, Faroogi MA, Aslam HMU, Majeed B, Sagheer M, Ali Q (2020) Compatibility of some botanicals and the entomopathogenic fungus, Beauveria bassiana (Bals.), against the red flour beetle, Tribolium castaneum (Herbst) (Coleoptera: Tenebrionidae). Egypt J Biol Pest Control 30:131

Samuels RI, Reynolds SE, Charnley AK (1988) Calcium channel activation of insect muscle by destruxins, insecticidal compounds produced by the entomopathogenic fungus Metarhizium anisopliae. Comp Biochem Physiol C Comparative 90(2):403-412. https://doi.org/10.1016/0742-8413(88)90018-7

Schroers HJ, Samuels GJ, Seifert KA, Gams W (1999) Classification of the mycoparasite Gliocladium roseum in Clonostachys as C. rosea, its relationship to Bionectria ochroleuca, and notes on other Gliocladium-like fungi. Mycologia 91(2):365-385. https://doi.org/10.1080/00275514.1999.12061028

Toledo A, Virla E, Humber R, Paradell S, Lastra CL (2006) First record of Clonostachys rosea (Ascomycota: Hypocreales) as an entomopathogenic fungus of Oncometopia tucumana and Sonesimi agrossa (Hemiptera: Cicadellidae) in Argentina. J Invertebr Pathol 92(1):7-10. https://doi.org/10.1 016/j.jip.2005.10.005

Xue AG (2003) Biological control of pathogens causing root rot complex in field pea using Clonostachys rosea strain ACM941. Phytopathology 93(3):329-335. https://doi.org/10.1094/PHYTO.2003.93.3.329

\section{Publisher's Note}

Springer Nature remains neutral with regard to jurisdictional claims in published maps and institutional affiliations.

\section{Submit your manuscript to a SpringerOpen ${ }^{\circ}$ journal and benefit from:}

- Convenient online submission

- Rigorous peer review

- Open access: articles freely available online

- High visibility within the field

- Retaining the copyright to your article

Submit your next manuscript at $\boldsymbol{\sim}$ springeropen.com 